Resumido por el autor, Charles Eugene Johnson.

El origen del cuerpo último-branquial y su relacion con la quinta bolsa visceral en las aves.

Las observaciones efectuadas por el autor en los embriones de gallina de agua (Fulica americana), gallinula, golondrina de mar, y gallina, demuestran que la verdadera quinta bolsa visceral de las aves es un divertículo diferente del que da origen al cuerpo último-branquial. Este cuerpo, al contrario de lo que se ha aceptado hasta ahora, no se forma a expensas de la quinta bolsa sino a expensas de un divertículo que se desarrolla medialmente a dicha bolsa. Observaciones efectuadas en la tortuga Chelydra serpentina y la comparación de los resultados mencionados con los obtenidos en otros reptiles, demuestran que la quinta bolsa y el divertículo último-branquial de las aves son homólogos con las estructuras correspondientes de los reptiles.

Translation by Dr. José Nonidez, Columbia Unlversity. 
ADTHOR'S ABSTRACT OF THIS PAPLR IRBUED BY

THE BIBLIOGRAPHIC GERVICE, NOVEMBER 18

\title{
THE ORIGIN OF THE ULTIMOBRANCHIAL BODY AND ITS RELATION TO THE FIFTH POUCH IN BIRDS
}

\author{
CHARLES EUGENE JOHNSON \\ Department of Animal Biology, University of Minnesota \\ TWO TEXT FIGURES AND TWO PLATES
}

The authority on which the accounts in text-books of embryology of the origin of the ultimobranchial body in birds are based is the work of Verdun ('98) on the chick. According to him, the ultimobranchial body arises from a diverticulum of the pharyngeal wall just behind the fourth visceral pouch. He calls this diverticulum the fifth visceral pouch, and he found it first in embryos of 124 hours. It was not present in embryos of 96 hours, he states, and at this stage the fourth pouch also was lacking. For an embryo of 148 hours he illustrates it as a caudally directed sac-like outpouching of approximately the same size as the fourth visceral pouch itself, at the base of which it opens into the pharynx through a wide mouth.

'In a survey of the literature on the subject in the chick one finds the accounts of the development of the ultimobranchial body and its relations to the fifth pouch rather indefinite and conflicting. Kastschenko ('87) found the so-called fifth pouch in a chick embryo of four days (illustrated in his figures 11 and 14, plate 19). Again in an embryo of six days he recognized a large 'bulbose Anschwellung' connected on one hand with the fourth visceral pouch and on the other with the pharynx, which "nichts anderes als die fünfte Schlundtasche darstellt." This fifth pouch, he states, has remained connected with the fourth pouch during the elongation of the latter and retains the connection also at a later period, after the two thymus anlagen have been separated from the pharyngeal wall. He refers to de Meu- 
ron's ('86) statement that this fifth pouch becomes detached from the pharynx and also from the fourth pouch in embryos of six days, but remarks that in his own material he did not observe the separation from the fourth pouch, although he examined a number of embryos of that age.

Mall ('87) derived the ultimobranchial body ('corpus y') from what was called by him the 'fossa subbranchialis' and which from his description differs in no way from the fifth pouch of Kastschenko and other authors. Mall mentions this fossa subbranchialis first, and illustrates it clearly, in the description of the visceral pouches of an embryo of three days, seven hours.

Liessner ('88) recognized the fifth pouch in embryos of 84 hours. At 120 hours, he states, the fifth pouches reach their maximum development and at 126 hours they have completely disappeared. The ultimobranchial body is not mentioned by Liessner, and the meaning of his statement that the fifth pouches disappear is not clear.

In none of the accounts of the development of the visceral pouches and the ultimobranchial body in the chick is there any reference to more than one diverticulum associated with the fourth visceral pouch, and all authors, with the exception of Mall, who describes the 'fossa subbranchialis' as an outpouching from the ventral aboral region of the fourth pouch, call this diverticulum the fifth visceral pouch.

In the duck and the house-sparrow (Passer domesticus) Kallius ('05) demonstrated the presence of a well-developed fifth visceral pouch, but the ultimobranchial body is not discussed by this author. On the other hand, Helgessen ('13) for the house-sparrow and Hamilton ('13) for the duck make no mention of a fifth visceral pouch, but derive the ultimobranchial body from the fourth pouch.

Rabl ('07) was the first to demonstrate the existence of two distinct diverticula in connection with the posterior wall of the fourth pouch, one of which represents the true fifth pouch and the other the anlage of the ultimobranchial body. His observations were made on the duck. The ultimobranchial diverticu- 
lum was interpreted by Rabl to represent a true sixth visceral pouch in birds.

My own observations ('17) have shown that two diverticula corresponding to those in the duck are developed in the piedbilled grebe. It is the purpose of the present paper to report the development of two such evaginations also in species representing two additional families of wild birds and in the chick.

Coot and gallinule. These two species present practically identical conditions. They show particularly well the relations of the fifth pouch and the ultimobranchial diverticulum in birds. Figure 3 represents the structures in this region of a gallinule (Gallinula galeata galeata Licht.) of approximately four and one-half days. The fourth pouch has a relatively long dorsoventral axis. The fifth pouch forms a narrower parallel diverticulum which is about three-fourths as long dorsoventrally as the fourth, is directed slightly more caudally, and at no point touches the ectoderm. The two pouches are at the end of a rather elongate common diverticulum of the pharynx which, because of an approximation of the two pouches in width, has the appearance in sections of being divided distally into twin lobes, very similar to the condition in the duck as described by Rabl. The fifth pouch of the left side is distinctly longer and broader than that of the right. The fifth aortic arches are complete. That of the left side lies in the angle between the fourth and the fifth pouch, i.e., in the fifth visceral arch, but the one on the right courses along the lateral border of the fifth pouch. The ultimobranchial diverticulum is just beginning to appear on the left side of the body as a slight bulging of the common pharyngeal diverticulum, medial to the fifth pouch.

Figure 5 represents the parts concerned in a coot (Fulica americana Gmel.) of about six days. The fifth pouch, though still conspicuous, is much reduced as compared with that of the four and one-half-day gallinule. The fifth aortic arch has in greater part disappeared, its dorsal end alone persisting as a short branch of the sixth. On the right side the diverticulum of the ultimobranchial body is not yet discernible, but on the left 
it is well differentiated and is situated entirely mediad of the fifth pouch, forming an evagination of the common pharyngeal diverticulum. This common pharyngeal diverticulum, as a result apparently of its further outgrowth and the consequent narrowing of its connection with the pharynx, together with the gradual reduction of the fifth pouch, now has more the appearance of being the fourth pouch proper, with the fifth pouch and the ultimobranchial diverticulum forming merely secondary outgrowths from its wall.

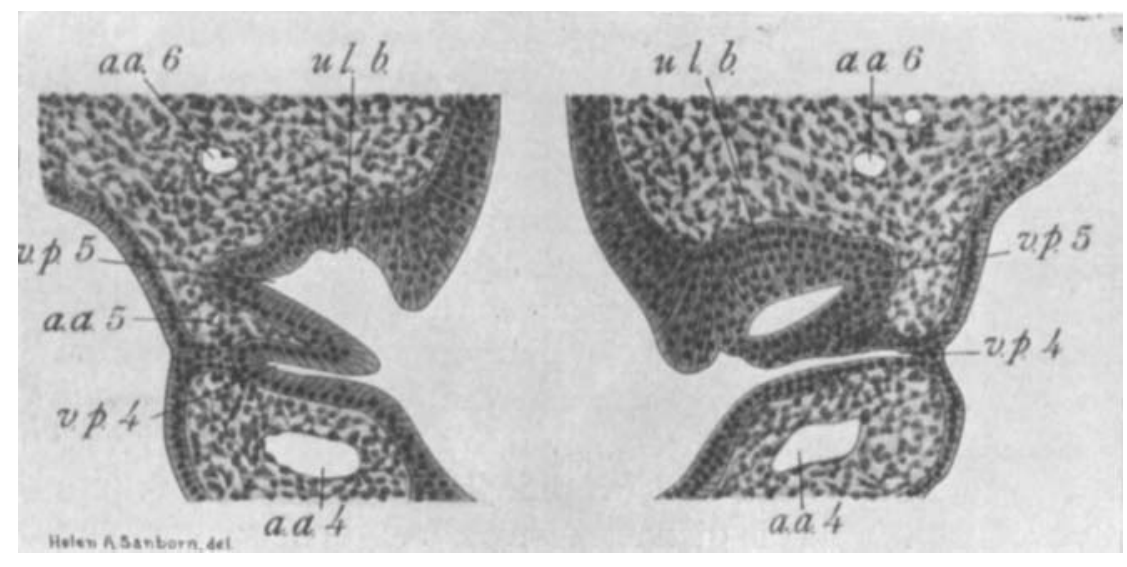

Fig. I Horizontal section through the region of the fourth and fifth visceral pouches and the ultimobranchial diverticulum of an embryo Forster's tern of four and one-half days. A.a.4,5,6, fourth, fifth and sixth aortic arches; $v . p .4,5$, fourth and fifth visceral pouches; ul.b., ultimobranchial body. $\times 112$.

Forster's tern. The youngest embryo of this tern (Sterna forsteri Nutt.) in my collection is one of about four and one-half days. In this specimen the fifth pouch is well developed (fig. 1). At its junction with the pharyngeal wall is a second clearly defined diverticulum, present on both sides of the embryo. This is the anlage of the ultimobranchial body. It differs from the corresponding diverticulum in the coot and the gallinule, in making its appearance somewhat earlier and in being more closely associated with the fifth pouch; but it agrees in these respects with the conditions presented by the four-day duck (Rabl). 
The only other embryo of this species in my possession of sufficiently early developmental stage to show remains of the fifth visceral pouch is a specimen of approximately six and one-half days. The pouch (fig. 6) is here on the verge of disappearing, but can be definitely identified in the sections. The ultimobranchial diverticulum is a relatively large outgrowth of globular form, sharply differentiated on both sides of the embryo, but that on the left considerably larger, as in the other species considered.

Chick. In the chick, judging from the available material only, the early steps in the development of the fifth pouch and the ultimobranchial diverticulum are not so clear as in the preceding species. In an 80-hour specimen there is a well-defined diverticulum having a form and relationship quite similar to the fifth pouch of the coot and the gallinule, in the early stages of the pouch in these forms. In a 90 -hour embryo the corresponding diverticulum is relatively very large, appearing actually larger than the fourth pouch itself, and is thicker-walled. In two 100-hour embryos this evagination appears to have reached its greatest development. It agrees in the main with the socalled fifth pouch as that has usually been described for the chick, forming a deep sac-like out-growth behind the fourth pouch, its blind end directed caudad and slightly laterad towards the ectoderm. It has a broader connection with the common pharyngeal diverticulum than had the fifth pouch in either the coot or the gallinule and is of more rounded form. It is also situated relatively nearer the pharyngeal wall, a situation which may have been brought about by a further lateral growth of the fourth pouch. In one of these specimens the so-called fifth pouch shows, on each side of the body, a slight indication of division into a lateral and a medial lobe, similar to the division shown in the four and one-half day tern, but the evidence in the present case is not so clear. One gains the distinct impression, however, in examining this so-called fifth pouch in the 100-hour and 96-hour embryos, that it represents something more than merely the fifth pouch, such as it is characterized in the other species discussed. From analogy with the relations of the fifth 
pouch and the ultimobranchial diverticulum in the tern it is possible that in the chick the two diverticula are coalesced in their early stages and only at a later period do they become distinguishable from each other, as the ultimobranchial body continues development while the fifth pouch becomes regressive. On the other hand is the possibility that in a more extensive series of chick embryos a condition similar to that in the tern may be found.

The next developmental stage at hand is represented by two embryos of five and one-half days. In both of these the ultimobranchial diverticulum is distinctly differentiated. Figure 4 is a wax reconstruction of the caudal pharyngeal diverticula of one of the embryos, made at a magnification of 200 diameters. The fourth visceral pouch was in close contact with the ectoderm. On the posterior wall of this pouch, where it joins the pharynx, are two distinct outpouchings. The lateral and smaller one clearly corresponds to the fifth pouch as it was represented in the preceding birds; the larger medial one is the ultimobranchial diverticulum. While the fifth pouch might here be interpreted as a secondary evagination from the fourth pouch, the ultimobranchial diverticulum is more clearly an outgrowth from the pharynx proper, and at this stage it opens into the pharyngeal eavity separately from the common mouth of the fourth and fifth pouches. The diverticulum as a whole is situated more ventrally than the fifth pouch. As in the other birds investigated, both the ultimobranchial diverticulum and the fifth pouch are better developed on the left side than on the right. Text figure 2 represents a transverse section through the middle of the fifth pouch of this embryo. The section cuts the ultimobranchial diverticulum at its junction with the pharyngeal wall, leaving the greater part of it posterior to the plane of the section.

In this embryo the fifth aortic arch could not be found on the left side, but on the right it was clearly represented by a short channel along the lateral side of the sixth arch, opposite the shallow groove formed between the fourth and fifth visceral pouches. 

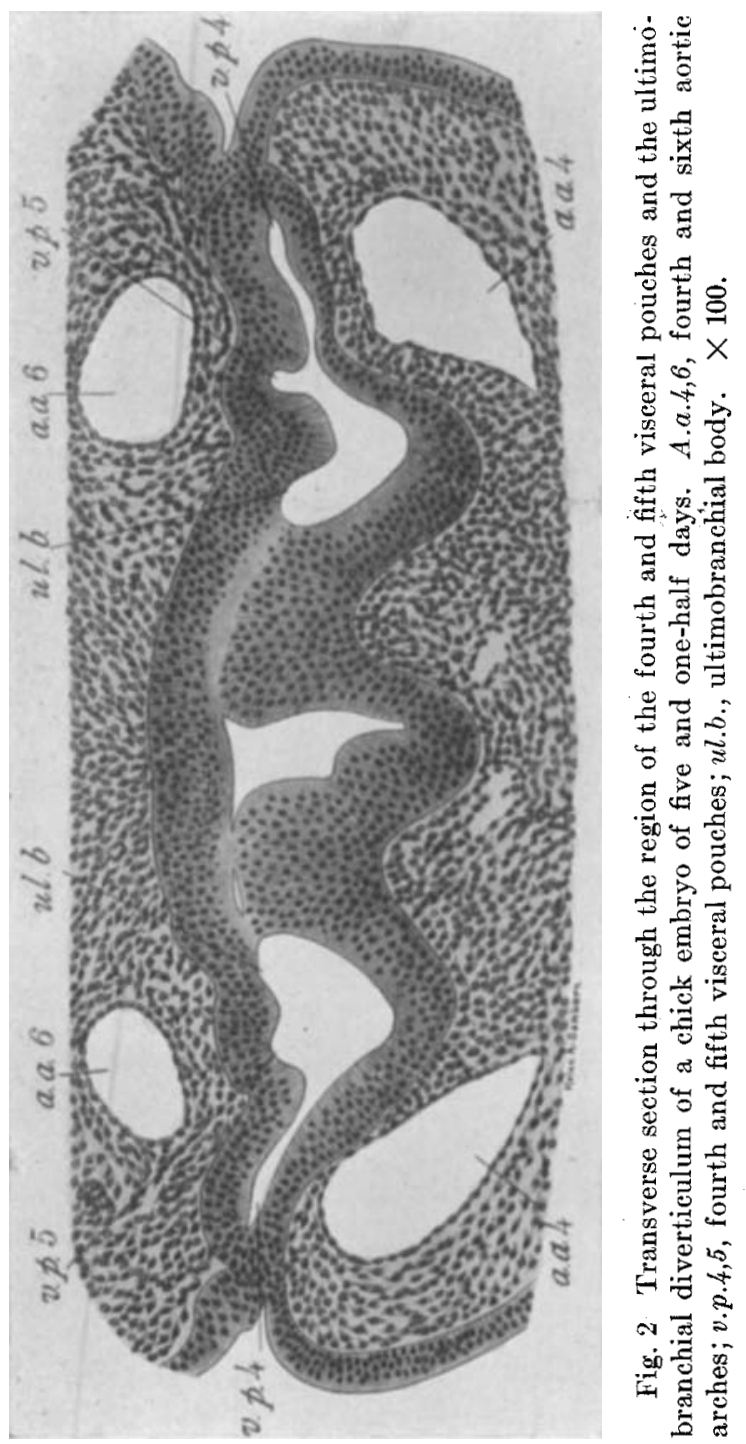


\section{DISCUSSION}

The evidence presented above shows that in birds a fifth visceral pouch is developed which is a different diverticulum from that which gives rise to the ultimobranchial body. This fifth pouch and the ultimobranchial diverticulum are strictly comparable to and homologous with the fifth pouch and the ultimobranchial diverticulum of reptiles.

For the lizards, Peter ('00) and Saint-Remy et Prenant ('03'04) in more recent years have demonstrated the presence of five visceral pouches, exclusive of the diverticulum giving rise to the ultimobranchial body. In Anguis fragilis, Lacerta viridis, and L. agilis, Saint-Remy et Prenant found that a relatively small fifth pouch is developed, which, however, soon disappears without leaving any trace. The left ultimobranchial body alone undergoes progressive development while the right usually vanishes, as in birds.

In the snakes these same authors also found five visceral pouches, but the fifth pouch here gives rise to a portion of the thymus and to a parathyreoid body. The ultimobranchial body persists on both sides.

In the turtles, van Bemmelen ('93) found that in Chelonia viridis (mydas) the fourth and fifth pouches are developed simultaneously with the ultimobranchial diverticulum from a lateral 'blinddarmförmigen Falte' at the posterior end of the pharynx. These pouches and the ultimobranchial anlage soon become pinched off from the pharynx and form a complex of three united vesicles.

In embryos of Chelydra serpentina I find that the structures in question arise in a similar way to those of Chelonia viridis. In an embryo of $6 \mathrm{~mm}$. the fourth and fifth pouches and the ultimobranchial diverticulum can be recognized in the form of three secondary outpouchings from a relatively large globular primary evagination of the pharynx. By the 9-mm. stage a deep constriction has appeared extending dorsoventrally in the transverse plane and separating the fourth pouch on the one hand from the fifth pouch and the ultimobranchial anlage on the other; 
but the two divisions thus formed are united at the base and connect with the pharynx through a common passage. The fifth pouch is a small elongate diverticulum arising from the lateral side of the ultimobranchial outpouching, i.e., where this outpouching joins the common pharyngeal stalk. It extends parallel with the fourth pouch and comes into close contact with the ectoderm. The right pouch is considerably larger than the left. On each side the pouch projects through the vascular ring formed by the fifth and sixth aortic arches, the fifth arch being very short and joining the sixth immediately above and below the pouch. The disparity in size between the fourth and the fifth pouch in the turtle at this stage is greater than that between the corresponding pouches in the four and one-half day gallinule. The ultimobranchial diverticulum on the other hand is relatively very much larger. Its place relations, however, are practically identical with those of the ultimobranchial diverticulum in the birds described.

The formation of the fifth visceral pouch and the ultimobranchial diverticulum in birds and in reptiles is essentially the same. In the reptiles, as represented by the turtles, these evaginations are differentiated simultaneously with the fourth visceral pouch from a common pharyngeal outpouching. This may possibly be explained by the relatively large pharyngeal area concerned with the formation of the ultimobranchial body. In the birds the fourth and fifth pouches appear first. The ultimobranchial body is somewhat retarded and its anlage involves a relatively smaller area. The fifth pouch of birds, like that of both lizards and turtles, is small and unimportant; apparently it only rarely gives rise to thymus tissue. The variations in its developmental details are probably governed by those of the greater and more important diverticula of the fourth pouch and the ultimobranchial body. 


\section{BIBLIOGRAPHY}

Baldwin, F. M. 1918 Pharyngeal derivatives of Amblystoma. Jour. Morph., vol. 30 .

Bemmelen, J. F. van 1893 Über die Entwickelung der Kiementaschen und der Aortenbogen bei den Seeschildkröten, untersucht an Embryonen von Chelonia viridis. Anat. Anz., Bd. 8.

1886 Die Visceraltaschen und Aortenbogen bei Reptilien und Vögeln. Zool. Anz., Bd. 9.

Greil, A. 1905 Über die Anlagen der Lungen, sowie der ultimobranchialen (postbranchialen, suprapericardialen) Körper bei anuren Amphibien.

Hamilton, B. 1913 Zur Embryologie der Vogelthymus. II. Die Thymusentwicklung bei der Ente, neben einigen Beobachtungen über die Kiemenspaltenorgane dieses Thieres. Anat. Anz., Bd. 44.

Helgessen, C. 1913 Zur Embryologie der Vogelthymus. I. Die Thymusentwicklung beim Sperling (Passer domesticus). Anat. Anz., Bd. 43.

Johnson, C. E. 1918 The branchial derivatives of the pied-billed grebe, with special consideration of the origin of the postbranchial body. Jour. Morph., v. 31.

Kallius, E. 1905 Beiträge zur Entwicklung der Zunge. II. Teil: Vögel.

Kastschenko, N. 1887 Das Schlundspaltengebiet des Hühnchens. Arch.f. Anat. u. Entwick.

KaLlicotr, W. E. 1913 Outlines of chordate development. Henry Holt \& Co., N. Y.

Liessner, E. 1888 Ein Beitrag zur Kenntnis der Kiemenspalten und ihrer Anlagen bei amnioten Wirbelthieren, Morph. Jahrb., 13.

Lillie, F. R. 1908 The development of the chick. Henry Holt \& Co., N. Y.

LocY, W. A. 1906 The fifth and sixth aortic arches in chick embryos with comments on the condition of the same vessels in other vertebrates. Anat. Anz. 29.

MaLL, F. P. 1887 Entwicklung der Branchialbogen und -Spalten des Hühnchens. Arch. f. Anat. u. Entwick.

MaURer, F. 1899 . Die Schildrüse, Thymus und andere Schlundspaltenderivate bei der Eidechse. Morph. Jahrb., 27.

Meuron, P. DE 1886 Recherches sur le dévellopement du thymus et de la glande thyroíde. Dissertation, Genéve.

Peter, K. 1900-1901 Mittheilungen zur Entwicklungsgeschichte der Eidechse. II. Die Schlundspalten und ihrer Anlage, Ausbildung und Bedeutung. Arch. f. mikr. Anat., Bd. 57.

RABL, H. 1907 Über die Anlage der ultimobranchialen Körper bei den Vögeln. Arch. f. mikr. Anat., Bd. 70.

Saint-Remy et Prenant 1903-04 Recherches sur le dévellopement des dérivés branchiaux chez les Sauriens et les Ophidiens. Arch. de Biol., 20.

Verdun, P. 1898 Dérivés branchiaux chez les vertebrés supérieurs. Thése, Toulouse. 
PLATES 


\section{PLATE 1}

\section{EXPLANATION OF FIGURES}

3 Posteroventral view of a wax reconstruction of the caudal portion of the pharynx and the associated aortic arches of an embryo gallinule of four and onehalf days. $\times 150$.

4 Posteroventral view of the caudal portion of the pharynx of a chick embryo of five and one-half days. $\times 150 . \quad A . a .4,5,6$, fourth, fifth and sixth aortic arches; A.p., pulmonary artery; A.v., ventral aorta; Oes., oesophagus; Tr., trachea; Ul.b., ultimobranchial body; V.p.4,5, fourth and fifth visceral pouches. 
ULTIMOBRANCHIAL BODY, FIFTH POUCH-BIRDS

PLATE 1

CHARLES EUGENE JOHNSON

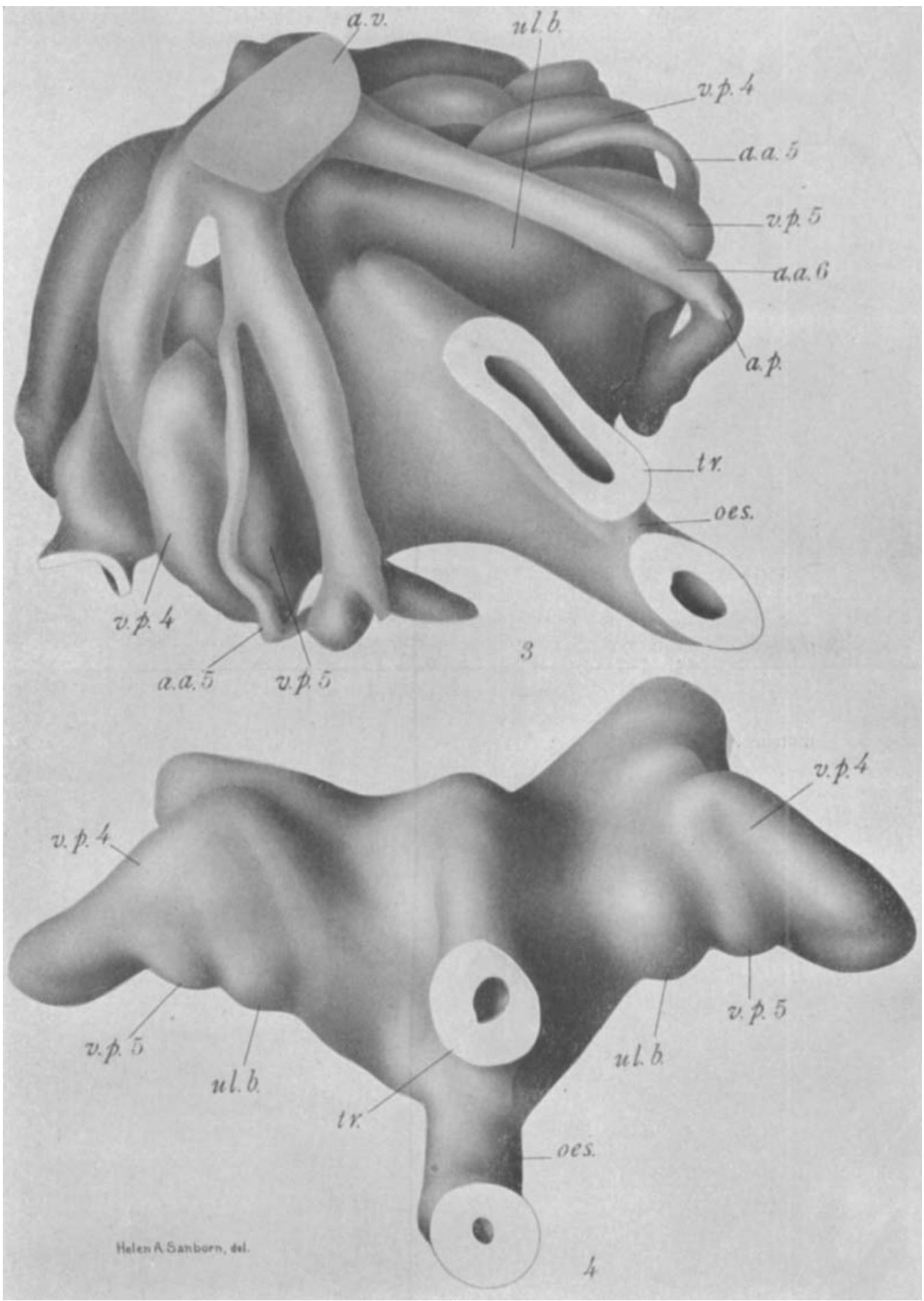




\section{PLATE 2}

\section{EXPLANATION OF FIGURES}

5 Posteroventral view of a wax reconstruction of the caudal portion of the pharynx and associated aortic arches of an embryo coot of six days. $\times 107$.

6 Posterodorsal view of a wax reconstruction of the caudal portion of the pharynx of an embryo Forster's tern of six and one-half days. $\times 107$. A.a.3,5,6, fourth, fifth, and sixth aortic arches; $A$.dor., dorsal aorta; A.p., pulmonary artery; $A . v$. , ventral aorta; C.ph.d., common pharyngeal diverticulum; Oes.,oesophagus; $T r .$, trachea; $U l . b$. . ultimobranchial body; V.p.4,5, fourth and fifth visceral pouches. 
ULTIMOBRANCHIAL BODY, FIFTH POUCH-BIRDS

PLATE 2

CHARLES EUGENE JOHNSON

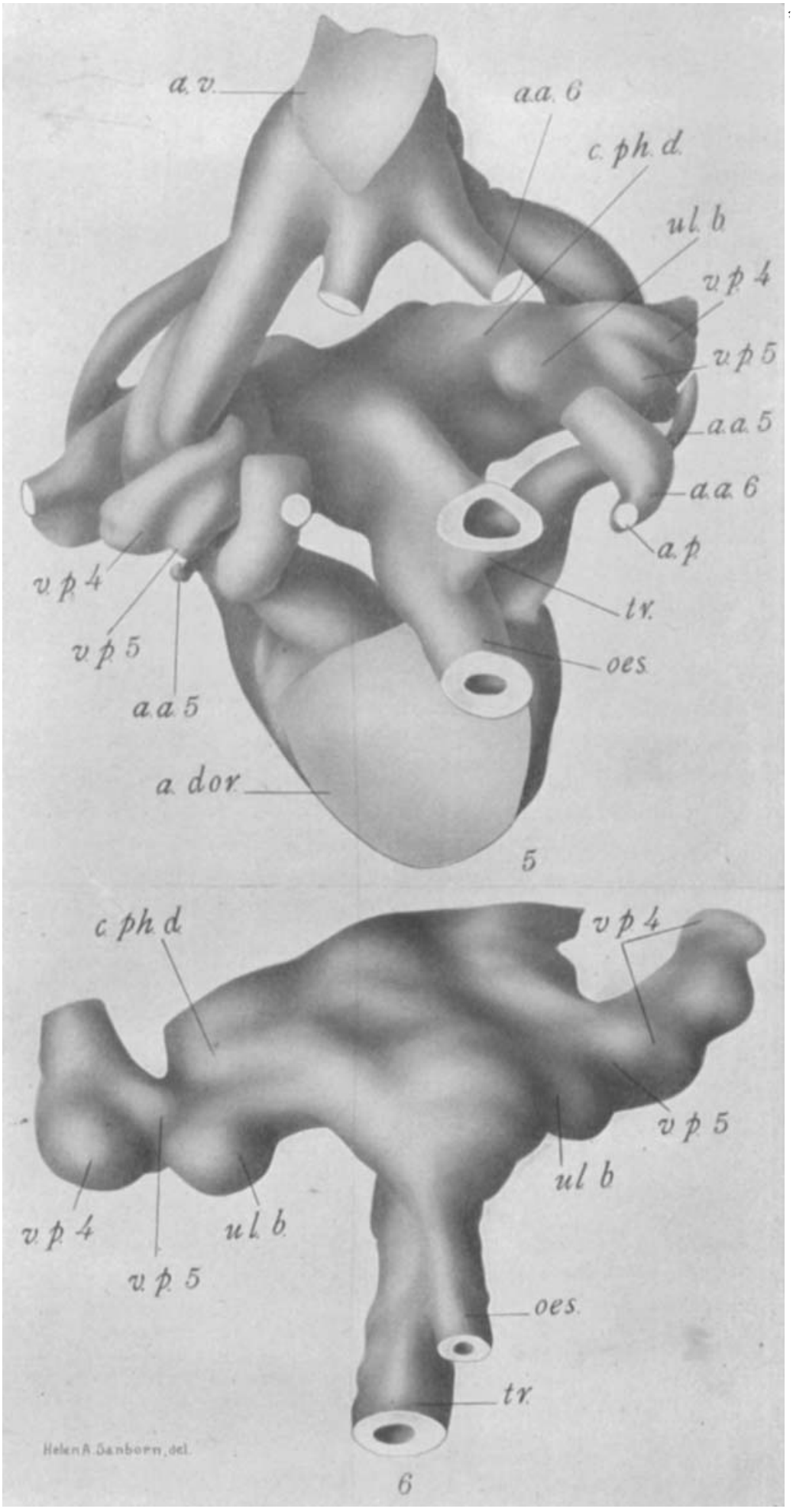

